\title{
KEPUASAN MASYARAKAT TERHADAP KUALITAS PELAYANAN KANTOR PERTANAHAN KABUPATEN INDRAMAYU
}

\author{
Slamet Riyadi ${ }^{12^{*}}$, Aji Hermawan ${ }^{3}$, Ujang Sumarwan ${ }^{4}$ \\ ${ }^{1}$ Kantor Pertanahan Kabupaten Indramayu, Indonesia \\ ${ }^{2}$ Program Studi Manajemen dan Bisnis, Sekolah Pascasarjana Institut Pertanian Bogor, Bogor 16151, Indonesia \\ ${ }^{3}$ Recognition and Mentoring Program-Institut Pertanian Bogor (RAMP-IPB), Bogor \\ ${ }^{4}$ Departemen Ilmu Keluarga dan Konsumen, Fakultas Ekologi Manusia, Institut Pertanian Bogor,
} Bogor 16680, Indonesia

")E-mail: slametriyadi_05@yahoo.com

\begin{abstract}
Abstrak
Penelitian kepuasan pelanggan tidak hanya dilakukan oleh dunia usaha saja akan tetapi juga dilakukan oleh pemerintah dalam rangka pelayanan publik. Kepuasan masyarakat dalam penelitian ini diukur melalui lima dimensi, yaitu reliability, responsiveness, assurance, empathy, dan tangible. Penelitian ini bertujuan untuk mengetahui tingkat kepuasan masyarakat terhadapa pelayanan Kantor Pertanahan Kabupaten Indramayu dan dimensi yang paling berpengaruh terhadap kepuasan masyarakat, yang nantinya akan dijadikan dasar dalam menentukan kebijakan. Berdasarkan hasil penelitian diperoleh tingkat kepuasan masyarakat terhadap kualitas pelayanan di Kantor Pertanahan Kabupaten Indramayu secara keseluruhan sudah cukup puas. Hal ini ditunjukkan oleh nilai rata-rata respon masyarakat sebesar 2,85 (dari nilai maksimum 4). Sementara itu, dimensi yang paling berpengaruh terhadap kepuasan masyarakat, yaitu emphaty dan tangible. Besarnya kontribusi dimensi empathy dan tangible terhadap kepuasan masyarakat ditunjukan oleh nilai loading factor, dimana masing-masing dimensi memiliki nilai sebesar 0,61 dan 0,41 dengan arah positif. Temuan ini menegaskan bahwa peningkatan kualitas pelayanan pada dimensi empathy dan tangible maka kepuasan masyarakat akan meningkat. Dari hasil tersebut dapat diambil beberapa alternatif kebijakan yang dapat ditempuh oleh Kantor Pertanahan Kabupaten Indramayu, yaitu membuat sistem komunikasi yang terintegrasi, penambahan jumlah pegawai loket, dan pembinaan terhadap pegawai melalui pelatihan.
\end{abstract}

Kata kunci: kantor pertanahan, kepuasan masyarakat, kualitas pelayanan, SEM

\section{The Public Satisfaction to Service Quality of Land Agency of Indramayu District}

\begin{abstract}
Customer satisfaction research is not only carried out by the business sector but also carried out by the government in the framework of public service. Satisfaction of the people in this study was measured by five dimensions that were reliability, responsiveness, assurance, empathy, and tangible. This study aimed to examine the level of public satisfaction to service quality of Land Agency of Indramayu District and the dimensions of the of the satisfaction that mostly influence, which will be used as the basis for determining policy. The results obtained that the level of public satisfaction to service quality as a whole was in quite satisfied. This was indicated by the value of the average society response of 2,85 (from maximum score of 4). Meanwhile, the dimensions of people's satisfaction that mostly influence were empathy and tangible. The amount of dimensions of empathy and tangible contribution to the satisfaction was indicated by the value of the loading factor; each dimension had a value of 0,61 and 0,41 with the positive direction. It means that increasing quality of service especially in empathy and tangible dimensions will increase the public satisfaction. Several policies from these results could be taken by the Land Agency of Indramayu District, such as creating an integrated communication system, increasing the number of employees on counters, and training for employees.
\end{abstract}

Keywords: public satisfaction, land agency, quality of service, SEM

\section{PENDAHULUAN}

Kepuasan pelanggan atau konsumen menjadi ukuran utama untuk kualitas pelayanan baik dibidang bisnis, manajemen maupun birokrasi. Suwarman et al. (2011) menyatakan bahwa kepuasan konsumen telah menjadi titik sentral perhatian dalam bisnis dan manajemen sehingga berbagai literatur yang menyangkut bisnis dan manajemen organisasi, baik yang bersifat mencari laba maupun nirlaba menempatkan kepuasan konsumen sebagai ukuran utama. Berkembangnya penelitian kepuasan pelanggan disebabkan hingga saat 
ini perusahaan meletakkan konsumen pada titik awal dari kegiatan perusahaan. Selain itu penelitian tentang kepuasan pelanggan bergeser ke arah birokrasi pemerintahan dalam rangka pelayanan publik, karena peningkatan kualitas pelayanan publik adalah sangat penting sebagai ujung akhir dari keseluruhan reformasi birokrasi. Oleh karena itu, kualitas pelayanan yang diselenggarakan oleh sektor publik sampai saat ini masih kurang memuaskan masyarakat. Pelayanan publik yang dilakukan birokrasi bukan melayani pelanggan (customer) tetapi melayani warga negara.

Pelayanan pemerintah adalah suatu kegiatan yang merupakan perwujudan dari salah satu fungsi pemerintah itu sendiri, yang mana tujuannya adalah untuk menyejahterakan masyarakat. Dalam kajian teoritis yang dilakukan oleh Mouw (2013) bahwa pelayanan publik di daerah menunjukkan manfaat dan keunggulannya, sekaligus juga menunjukkan kelemahannya. Harapan masyarakat yang selalu menginginkan kepuasan dalam pelayanan, namun kelemahan birokrat pada ketiadaan atau terbatasnya sumber daya yang mumpuni serta ditambah dengan peraturan-peraturan yang membuat birokrat daerah bekerja dengan kaku. Sehingga masih banyaknya keluhan masyarakat atas rendahnya kualitas pelayanan publik.

Pada kenyataannya masih banyak pengaduan (keluhan) atau pernyataan ketidakpuasan masyarakat terhadap kualitas pelayanan publik. Pelayanan publik menjadi titik strategis yang mana kepercayaan masyarakat secara luas kepada pemerintah dipertaruhkan. Berbagai kebijakan nasional dalam rangka meningkatkan kualitas pelayanan publik tersebut telah memberikan fondasi bagi instansi pemerintah untuk melakukan upaya nyata dalam mereformasi pelayanan untuk meningkatkan kepuasan masyarakat atau pelanggan.

Menurut Kotler (2000), kepuasan merupakan perasaan seseorang mengenai kesenangan atau kepuasan atau hasil yang mengecewakan yang diperoleh dari hasil membandingkan penampilan produk yang telah disediakan dengan harapan pelanggan. Jadi dapat disimpulkan bahwa kepuasan adalah perasaan senang atau kecewa yang dimiliki seseorang berdasarkan perbandingan antara kenyataan yang diperoleh dengan harapan yang diinginkan. Terkait dengan kepuasan masyarakat terhadap pelayanan Kantor Pertanahan Kabupaten Indramayu, terdapat beberapa masalah yang dihadapi, yaitu menurunnya jumlah pengurus sertifikat yang datang secara langsung di Kantor Pertanahan, minimnya sosialisasi terhadap masyarakat tentang penyertifikatan tanah, dan kurangnya sarana dan prasarana yang memadai.

Beberapa penelitian terdahulu yang relevan dengan penelitian ini yaitu: (1) Dariah (2008) menganalisis tentang pengaruh kualitas pelayanan terhadap kepuasan masyarakat dalam mengurus sertifikat tanah pada Kantor Pertanahan di Kabupaten Banjarmasin. Hasil penelitian yang diperoleh yaitu dimensi yang paling berpengaruh yaitu dimensi keandaalan (reliability), (2) Supraworo (2009) meneliti tentang analisis Indeks Kepuasan Masyarakat (IKM) terhadap kinerja pelayanan publik bidang pertanahan dalam proses balik nama di Kantor Pertanahan Kabupaten Semarang. Hasil penelitian yang diperoleh bahwa mutu pelayanan publik kantor pertanahan kabupaten semarang khususnya dalam hal proses balik nama pada peralihan hak karena jual-beli masih kurang padahal keberadan kantor pertanahan kabupaten semarang untuk pelayanan di bidang pertanahan sangat penting, (3) Suharno (2002) meneliti tentang persepsi masyarakat terhadap penyertifikatan tanah (kasus di Desa Girikerto Kecamatan Turi Kabupaten Sleman). Hasil penelitian diperoleh bahwa persepsi masyarakat terhadap penyertifikatan tanah di kabupaten Sleman masih bersifat negatif.

Ketiga penetilian tersebut masih memerlukan penelitian lebih lanjut, yaitu tentang pemodelan struktural dari kualitas pelayanan dan kepuasan masyarakat. Adapun yang membedakan penelitian ini dengan penelitian tersebut yaitu: (1) Tempat penelitian ini dilakukan di daerah indramayu; (2) Analisis yang digunakan dengan menggunakan SEM; (3) Konsertrasi penelitiannya untuk mengetahui indikator yang paling berpengaruh terhadap kepuasan masyarakat.

Penelitian ini bertujuan untuk menganalisis pengaruh tingkat pelayanan terhadap kepuasan masyarakat di Kantor Pertanahan Kabupaten Indramayu. Selain itu, penelitian ini juga bertujuan untuk menganalisis dimensi yang paling berpengaruh terhadap kepuasan masyarakat. Hasil penelitian yang diperoleh akan dijadikan dasar dalam mengevaluasi program dan menentukan kebijakan. 


\section{METODE}

Penelitian ini dilakukan di Kantor Pertanahan Kabupaten Indramayu, Jawa Barat pada bulan April hingga Juli 2014. Desain yang digunakan dalam penelitian ini yaitu crosssectional. Penelitian ini melibatkan 132 orang sebagai responden. Responden yang ditemui adalah responden yang sedang mengambil sertifikat atau melakukan pendaftaran pembuatan sertifikat. Pengambilan sampel menggunakan teknik convenience sampling yaitu dengan cara mendatangi masyarakat yang mengambil sertifikat hak milik di loket penyerahan produk Kantor Pertanahan Kabupaten Indramayu untuk diberikan kuesioner.

Tingkat kepuasan masyarakat diukur melalui lima dimensi kualitas pelayanan yaitu reliability, responsiveness, assurance, emphaty, dan tangibles (Parasuraman, 1998). Masingmasing dimensi dijabarkan menjadi lima indikator, sehingga terdapat 25 indikator. Skala pengukuran yang digunakan adalah skala jawaban Likert, yang mana skala ini mengurutkan data dari tingkat yang paling rendah ke tingkat yang paling tinggi atau sebaliknya dengan interval yang tidak harus sama. Skala $1=$ "sangat tidak puas", diberi bobot 1 , Skala $2=$ "tidak puas", diberi bobot 2 , skala $3=$ "cukup puas", diberi bobot 3, skala 4= "puas", diberi bobot 4 , dan skala $5=$ "sangat puas", diberi bobot 5. Tahapan analisis data dalam penelitian ini yaitu, analisis deskriptif, pengujian kecocokan model SEM (Tabel 1), dan analisis loading factor. Tujuan dari analisis deskriptif untuk mengetahui rata-rata dari setiap indikator kualitas pelayanan, kecocokan model SEM untuk mengetahui apakah model yang dibangun sesuai atau tidak, dan loading factor untuk mengetahui pengaruh dimensi yang paling besar terhadap kepuasan masyarakat. Hasil uji kecocokan model ditampilkan pada Tabel 1.

Berdasarkan kriteria goodness of fit index diketahui bahwa semua kriteria yang digunakan sebagai alat uji untuk menentukan kecocokan model estimasi dengan model yang didasarkan pada data empiris menunjukkan nilai yang baik. Hal ini dapat diketahui dari semua nilai goodness of fit lebih besar daripada nilai cut off value yang ditentukan dimana cut off value merupakan indeks yang digunakan untuk menentukan tingkat kecocokan model. Data tersebut menunjukan bahwa model estimasi yang diajukan cocok atau sesuai dengan model sampel yang didasarkan pada data empiris.
Tabel 1 Uji kecocokan pada beberapa kriteria Goodness of Fit Index

\begin{tabular}{lrrr}
\hline \multicolumn{1}{c}{ Goodnes-of-fit } & \multicolumn{1}{c}{ Hasil } & Cut-of-Value & Kriteria \\
\hline Chi-Square (X2) & 523,82 & $\begin{array}{r}\text { Diharapkan } \\
\text { kecil }\end{array}$ & Baik \\
$\begin{array}{l}\text { Significance } \\
\text { Probability ( } p \text { - }\end{array}$ & 0,65 & $\geq 0,05$ & Baik \\
value) & & & \\
RMSEA & 0,05 & $\leq 0,08$ & Baik \\
GFI & 0,98 & $\geq 0,90$ & Baik \\
AGFI & 0,93 & $\geq 0,90$ & Baik \\
CFI & 0,98 & $\geq 0,95$ & Baik \\
CN & 257,83 & $>200$ & Baik \\
\hline
\end{tabular}

HASIL

Profil responden berdasarkan kategori usia, responden yang paling banyak adalah usia 26-35 tahun sebanyak 53 orang. Jumlah yang paling sedikit pada usia dibawah 15 tahun sebanyak 1 orang. Untuk usia 36-45 tahun sebanyak 50 orang, usia 21-25 tahun sebanyak 24 orang dan sisanya masing berjumlah 2 orang. Kondisi sebaran usia ini sudah cukup mewakili populasi responden yang mengurus pembuatan sertifikat secara langsung.Tingkat pendidikan responden dalam penelitian ini yang paling banyak adalah SMA sebanyak 102 orang. Sedangkan yang paling sedikit adalah S2 sebanyak 1 orang. Adapun pendidikan lainnya, yaitu S1, Diploma dan SMP berturutturut sebanyak 11 orang, 5 orang dan 11 orang. Tingkat pendidikan responden ini didominasi oleh SMU. Jenis pekerjaan responden dalam penelitian ini adalah pekerjaan sebagai ibu rumah tangga sebanyak 8 orang, akademisi 2 orang, dan wiraswasta sebanyak 99 orang. Kemudian pekerjaan PPAT/notaris sebanyak 5 orang, petani 9 orang, dan PNS/TNI/Polri sebanyak 2 orang. Sedangkan jenis pekerjaan lain sebanyak 7 orang.

Berdasarkan hasil pengolahan data diperoleh nilai rata-rata dari indikator pembentuk dimensi reliability, yaitu kejelasan pemberian informasi pelayanan $\left(X_{1}\right)$ sebesar 3,01 , kesederhanaan prosedur pelayanan $\left(X_{2}\right)$ sebesar 2,81 , biaya yang dikeluarkan sesuai dengan yang dijanjikan $\left(X_{3}\right)$ sebesar 2,57, ketepatan pengecekan persyaratan $\left(X_{4}\right)$ sebesar 2,70 dan ketepatan waktu penyelesaian sertifikat $\left(X_{5}\right)$ sebesar 2,46 . Dari kelima indikator tersebut, indikator $X_{1}, X_{2}$ dan $\mathrm{X}_{4}$ mendapatkan penilaian cukup memuaskan, sedangkan indikator lainnya kurang memuaskan. Hasil ini menunjukan bahwa kemampuan Kantor Pertanahan Kabupaten Indramayu dalam menampilkan pelayanan yang akurat kurang memuaskan khususnya 
dalam hal ketepatan waktu penyelesaian sertifikat dan biaya.

Nilai rata-rata dari indikator pembentuk dimensi responsiveness, yaitu kecepatan petugas dalam memberikan pelayanan $\left(X_{6}\right)$ sebesar 2,81 , daya tanggap petugas dalam menindaklanjuti keluhan yang dihadapi oleh masyarakat $\left(\mathrm{X}_{7}\right)$ sebesar 2,71 , daya tanggap petugas dalam menyampaikan informasi yang dibutuhkan oleh masyarakat secara tepat $\left(X_{8}\right)$ sebesar 2,77, kesigapan petugas dalam membantu masyarakat menyelesaikan masalah yang terjadi $\left(\mathrm{X}_{9}\right)$ sebesar 2,77 , dan kesediaan petugas dalam merespon dengan cepat terhadap kritik dan saran yang disampaikan oleh masyarakat dalam rangka meningkatkan kualitas layanan $\left(X_{10}\right)$ sebesar 2,62 . Hasil ini berarti keseluruhan indikator mendapat penilaian yang cukup memuaskan. Hal ini menunjukkan bahwa kemampuan petugas di Kantor Pertanahan Kabupaten Indramayu dalam menyediakan pelayanan yang cepat dan memuaskan sudah sesuai dengan harapan masyarakat.

Sementara itu, nilai rata-rata dari indikator pembentuk dimensi assurance, yaitu kemampuan menjawab $\left(X_{11}\right)$ sebesar 2,92, kesopanan $\left(X_{12}\right)$ sebesar 2,86, kemampuan memberikan rasa aman $\left(X_{13}\right)$ sebesar 2,85 , tanggug jawab $\left(X_{14}\right)$ sebesar 2,77 dan kesiapan pegawai melayani tepat waktu $\left(\mathrm{X}_{15}\right)$ sebesar 2,57. Hasil ini berarti keseluruhan indikator mendapatkan respon yang cukup memuaskan dari responden. Hal ini menunjukkan kemampuan Kantor Pertanahan Kabupaten Indramayu dalam memberikan pelayanan yang nyaman.

Dimensi keempat yaitu emphaty, memperoleh nilai rata-rata dari masing-masing indikator, yaitu perhatian pegawai terhadap kebutuhan masyarakat $\left(X_{16}\right)$ sebesar 2,92, keramahan pegawai $\left(X_{17}\right)$ sebesar 2.88, kemampuan pegawai mendengarkan keluhan masyarakat $\left(X_{18}\right)$ sebesar 2,65 , perilaku adil pegawai $\left(X_{19}\right)$ sebesar 2.60 , dan kemudahan masyarakat dalam mendapatkan informasi $\left(X_{20}\right)$ sebesar 2,70. Data ini menunjukkan respon yang cukup puas oleh masyarakat dan dapat disimpulkan bahwa empati para pegawai sudah cukup baik.

Dimensi terakhir yaitu tangible, memperoleh nilai rata-rata dari masing-masing indikator, yaitu kerapian penampilan petugas $\left(X_{21}\right)$ sebesar 2,85, kenyamanan ruang tunggu pelayanan $\left(X_{22}\right)$ sebesar 3,57 , kebersihan ruang tunggu pelayanan $\left(X_{23}\right)$ sebesar 3,20 , memiliki tempat parker yang luas $\left(\mathrm{X}_{24}\right)$ sebesar 2.99, dan pemeliharaan informasi papan pengumuman $\left(X_{25}\right)$ sebesar 2,58. Lima indikator pembentuknya tersebut mendapatkan respon yang cukup puas dari masyarakat. Hal ini menunjukkan bahwa tangible di Kantor Pertanahan Kabupaten Indramayu, sudah cukup baik.

Selanjutnya, untuk mengetahui besarnya dan arah hubungan linier dua indikator dimensi kualitas pelayanan maka dilakukan analisis korelasi menggunakan nilai kovariansi dari masing-masing hubungan antar indikator pembentuk dimensi kualitas pelayanan. Nilai matriks kovarians yang dihasilkan Lisrel menunjukkan bahwa lima hubungan antar indikator pembentuk dimensi kualitas pelayanan yang memiliki pengaruh terbesar dalam peningkatan kepuasan masyarakat yaitu: (1) hubungan antara indikator keramahan sikap pegawai dengan indikator kemampuan pegawai mendengar keluhan masyarakat dimana nilai koefisien korelasi yang ditunjukkan sebesar 0,70 , (2) hubungan antara indikator kemampuan petugas dalam memberikan rasa aman kepada masyarakat dengan indikator kemampuan petugas menjawab pertanyaan masyarakat dimana nilai koefisien korelasi yang ditunjukkan sebesar 0,76, (3) hubungan antara indikator keramahan petugas dengan indikator kemampuan petugas dalam memberikan rasa aman kepada masyarakat dimana nilai koefisien korelasi yang di tunjukkan sebesar 0,73 , (4) hubungan antara indikator keramahan petugas dengan indikator prosedur pelayanan dimana nilai yang ditunjukkan sebesar 0,85, (5) hubungan antara indikator ketepatan waktu penyelesaian dengan indikator kemampuan petugas dalam memberikan rasa aman kepada masyarakat pada saat proses pengurusan sertifikat dimana nilai yang ditunjukkan sebesar 0,78 .

Dari lima hubungan tersebut diketahui bahwa perilaku petugas terhadap masyarakat sebagai pengguna layanan memiliki peran yang sangat penting dalam kepuasan masyarakat. Perilaku tersebut meliputi keramahan petugas, kemampuan membuat rasa aman bagi masyarakat, serta kesediaan petugas mendengar keluhan masyarakat. Perilaku petugas sebagai fasilitator pelayanan publik merupakan hal yang penting untuk diketahui mengingat hal tersebut berguna untuk menunjang kemampuan petugas dalam memberikan layanan terbaiknya (pelayanan prima) bagi masyarakat pengguna layanan. $\mathrm{Hal}$ ini sejalan dengan pendapat Barata (2006) yang menempatkan perilaku sebagai salah satu 
aspek pembentukan sikap seseorang yang mana sikap seseorang sangat dipengaruhi oleh berbagai faktor yang dapat meningkatkan kemampuan diri.

Barata (2006) selanjutnya menyatakan bahwa kemampuan diri merupakan kemampuan minimal yang harus ada pada diri seseorang terkait dengan wawasan pengetahuan dan ketrampilannya, yaitu memiliki pengetahuan dan ketrampilan sesuai dengan bidang tugasnya, memiliki daya kreativitas cukup baik, memahami cara berkomunikasi dengan baik, memahami pengetahuan dasar hubungan interpersonal dan psikologi sosial, memahami cara memposisikan diri dalam berbagai situasi sehingga mudah beradaptasi dengan lingkungan dan mampu mengendalikan emosi. Kemampuan diri tesebut merupakan sebagian ciri pribadi yang memiliki pengetahuan prima dibidang tugasnya sehingga diharapkan dapat menjadikan petugas sebagai fasilitator pelayanan publik menjadi pribadi yang memiliki kemampuan prima dan dapat mengembangkan budaya pelayanan prima dilingkungan kerja dimana tujuan akhir dari layanan yang prima adalah untuk kepuasan pelanggan. Untuk mengetahui kontribusi dari setiap indikator kepada masing-masing dimensi kepuasan dapat diketahui melalui gambar SEM. Dari hasil pengolahan data diperoleh model SEM (Gambar 1).

Indikator yang memiliki kontribusi terbesar dalam menjelaskan dimensi reliability menurut Gambar 1. adalah indikator kepaastian biaya pelayanan $\left(X_{3}\right)$ sebesar 0,49 . Hal ini kontradiksi dengan hasil rata-rata respon masyarakat yang menyatakan kurang puas terhadap kepastian biaya. Perbedaan ini adalah wajar, karena perhitungan biaya pelayanan pembuatan sertifikat sangat bervariasi tergantung pada luasnya tanah. Tetapi ada biaya standar permeternya, hal inilah yang menyebabkan kontribusi kepastian biaya cukup tinggi.

Indikator kejelasan pemberian informasi pelayanan $\left(X_{1}\right)$ memliki kontribusi sebesar 0,35 indikator kesederhanaan prosedur pelayanan $\left(X_{2}\right)$ memiliki kontribusi nilai sebesar 0,29 indikator kepastian persyaratan pelayanan $\left(\mathrm{X}_{2}\right)$ memiliki kontribusi nilai sebesar 0,33. Kemudian indikator $X_{5}$ memiliki kontribusi nilai sebesar 0,30. Dari hasil tersebut mengindikasikan bahwa dari kelima indikator variabel laten, ketepatan waktu penyelesaian sertifikat dan kesederhanaan prosedur pelayanan menjadi faktor yang kurang dominan dalam pembentukan dimensi reliability dan diprioritaskan untuk dapat diperbaiki kualitas pelayanannya. Hal ini kurang sesuai dengan aturan pemerintah yang dituangkan dalam keputusan Menpan Nomor 8 tahun 1993 yang seharusnya dijadikan pedoman oleh setiap instansi pelayanan publik sebagai aturan dalam setiap penyelenggaraan pelayanan umum dimana aturan tersebut menetapkan 8 sendisendi pelayanan prima.

Salah satu aspek yang termasuk dalam sendi pelayanan prima yang kurang sesuai dengan hasil penelitian ini adalah ketepatan waktu. Ketidaksesuaian tersebut disebabkan oleh banyak faktor, diantaranya keterlambatan pemohon dalam melengkapi berkas dan adanya masa pengumuman permohonan selama 2 bulan untuk memberikan tenggang waktu kepada masyarakat yang berkeberatan sebelum sertifikat diterbitkan.

Indikator $\mathrm{X}_{7}$ memiliki kontribusi nilai terbesar dibandingkan keempat indikator lainnya dalam menjelaskan dimensi responsiveness sebesar 0,48 kemudian diikuti oleh indikator $\mathrm{X}_{6}$ memiliki kontribusi nilai sebesar 0,44 . Indikator $X_{8}$ memiliki kontribusi nilai sebesar 0,26. Indikator $X_{9}$ memiliki kontribusi nilai sebesar 0,38. Indikator $X_{10}$ berkontribusi sebesar 0,33. Berdasarkan hasil tersebut, dari kelima indikator variabel laten, daya tanggap pegawai terhadap keluhan masyarakat dan kecepatan pegawai dalam memberikan pelayanan, menjadi faktor dominan dalam pembentukan dimensi responsiveness dan diprioritaskan untuk dapat dipertahankan kualitas pelayanannya. Kedua indikator tersebut ternyata belum tercakup dalam aspek dari sendi-sendi pelayanan prima dimana 8 sendi pelayanan prima sebagaimana keputusan Menpan nomor 8 tahun 1993 lebih menekankan pada aspel teknis saja sementara dari aspek perilaku petugas sebagai aparat pelayanan publik belum tercakup dalam ketentuan tersebut.

Indikator yang memiliki kontribusi terbesar dalam membentuk dimensi assurance adalah indikator kemampuan pegawai menjawab pertanyaan-pertanyaan masyarakat $\left(X_{11}\right)$ dengan nilai sebesar 0,59 , kemudian diikuti oleh indikator $\mathrm{X}_{12}$ berkontribusi sebesar 0,58 . Indikator $X_{13}$ berkontribusi sebesar 0,44. Indikator $X_{14}$ berkontribusi sebesar 0,41. Sedangkan indikator terakhir yaitu indikator $X_{15}$ berkontribusi sebesar 0,28. Hal ini mengindikasikan bahwa dari kelima indikator variable laten, kemampuan pegawai menjawab pertanyaan-pertanyaan masyarakat dan kesopanan pegawai dalam memberikan 
pelayanan menjadi faktor dominan dalam pembentukan dimensi assurance dan

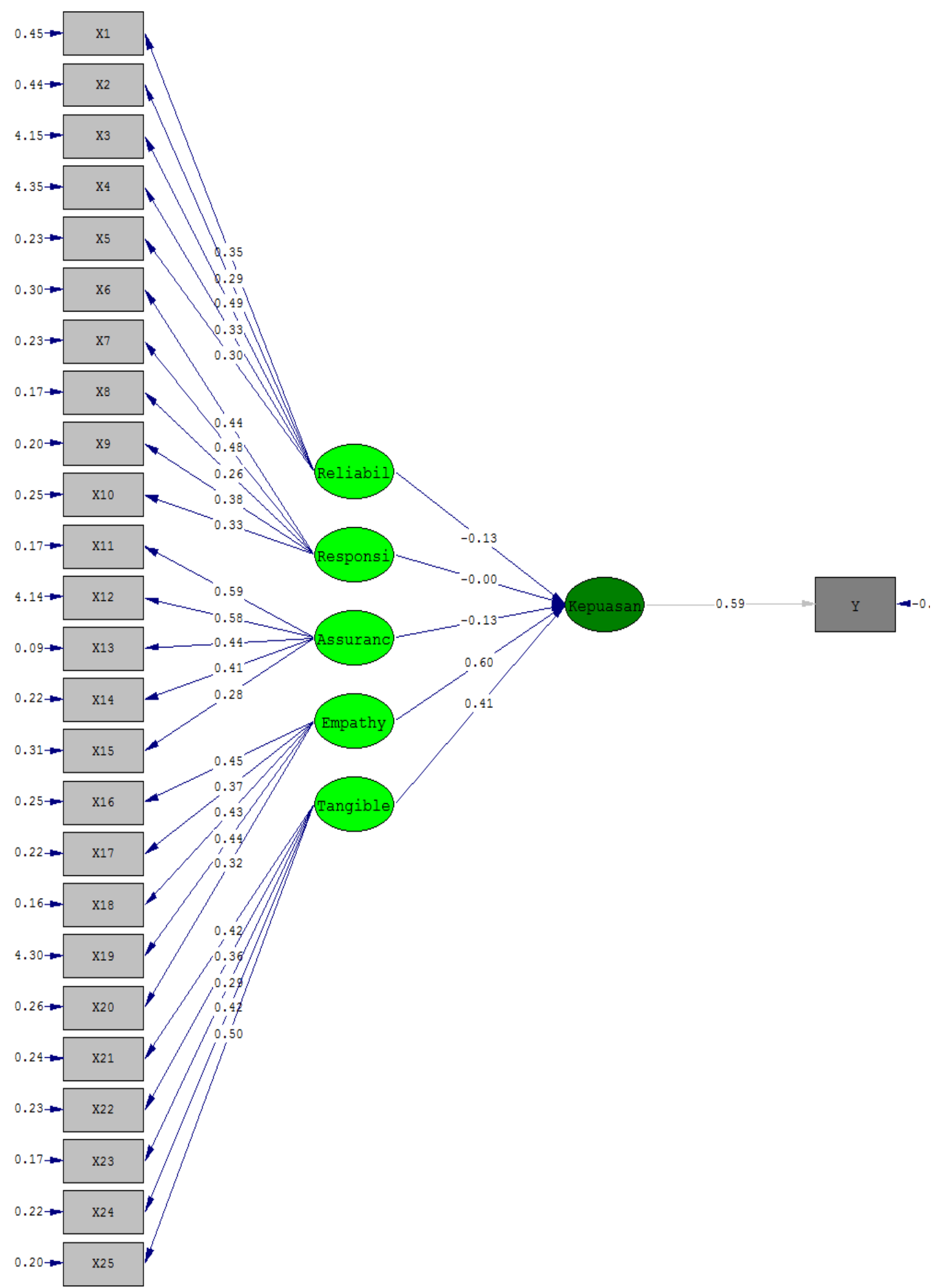

diprioritaskan untuk dapat dipertahankan bahkan ditingkatkan kualitas pelayanannya. 
Hasil penelitian ini sangat sesuai dengan respon masyarakat yang menyatakan puas terhadap kemampuan pegawai menjawab pertanyaan-pertanyaan masyarakat dan kesopanan pegawai dalam memberikan pelayanan. Hal ini sangat mendukung perwujudan aspek mental pelayanan dari sendisendi pelayanan prima dimana pada aspek tersebut diharapkan instansi pelayanan publik dapat memberikan pelayanan yang santun. Artinya dengan tumbuhnya kesopanan dan kesantunan terhadap pelayanan yang diberikan diharapkan dapat membuat masyarakat merasa nyaman dan percaya terhadap Kantor Pertanahan Kabupaten Indramayu baik pada saat proses pelayanan dilakukan maupun setelah hasil dari pelayanan tersebut diterima masyarakat.

Indikator yang memiliki kontribusi terbesar dalam membentuk dimensi emphaty adalah perhatian pegawai terhadap kebutuhan masyarakat dengan nilai 0,45 . Kemudian diikuti perilaku adil pegawai pada masyarakat $\left(\mathrm{X}_{16}\right)$ dengan nilai 0,44 . Indikator kemampuan pegawai mendengar keluhan berkontribusi sebesar 0,43. Indikator keramahan sikap pegawai berkontribusi sebesar 0,37. Sedangkan indikator yang paling rendah adalah indikator kemudahan mendapatkan informasi proses penyelesaian sertifikat yang berkontribusi sebesar 0,32. Berdasarkan data tersebut mengindikasikan bahwa diantara lima indikator pembentuk dimensi empathy, perhatian pegawai terhadap kebutuhan masyarakat, perlakuan adil pegawai pada masyarakat dan kemampuan pegawai mendengarkan keluhan, menjadi faktor yang lebih dominan dalam pembentukan dimensi empathy terhadap kepuasan masyarakat dan diprioritaskan untuk dipertahankan dan ditingkatkan. Sedangakan indikator yang berkontribusi paling rendah yaitu kemudahan mendapatkan informasi proses penyelesaian sertifikat wajib ditingkatkan agar masyarakat lebih puas terhadap pelayanan Kantor Pertanahan Kabupaten Indramayu.

Indikator yang memiliki kontribusi terbesar dalam membentuk dimensi tangible adalah pemeliharaan informasi papan pengumuman dengan nilai 0,50 . Kemudian diikuti memiliki tempat parkir yang luas $\left(\mathrm{X}_{24}\right)$ dengan nilai 0,42 . Indikator kerapihan penampilan pegawai berkontribusi sebesar 0,42. Indikator kenyamanan ruang tunggu berkontribusi sebesar 0,36. Sedangkan indikator yang paling rendah adalah indikator kebersihan ruang tunggu pelayan yang berkontribusi sebesar 0,32. Berdasarkan data tersebut mengindikasikan bahwa diantara lima indikator pembentuk dimensi tangible, pemeliharaan informasi papan pengumuman, kerapihan penampilan pegawai, dan memiliki tempat parkir yang luas, menjadi faktor yang lebih dominan dalam pembentukan dimensi tangible terhadap kepuasan masyarakat dan diprioritaskan untuk dipertahankan dan ditingkatkan. Sedangkan indikator yang berkontribusi paling rendah yaitu kebersihan ruang tunggu pelayanan wajib ditingkatkan agar masyarakat lebih puas terhadap pelayanan Kantor Pertanahan Kabupaten Indramayu.

Berdasarkan dimensi kualitas pelayanan yang membentuk kepuasan masyarakat memiliki nilai loading factor tersendiri yang merupakan ukuran seberapa besar dimensi tersebut menjadi variabel pembentuk dalam meningkatkan kepuasan masyarakat. Hasil dari pengolahan data menggunakan Lisrel menunjukan besaran loading factor untuk dimensi kualitas pelayanan sebagaimana terlihat pada Tabel 2.

Berdasarkan hasil responsi masyarakat, dimensi empathy dan tangible yang berpengaruh sangat signifikan terhadap kepuasan masyarakat dalam kualitas pelayanan di Kantor Pertanahan Kabupaten Indramayu. Sebanyak lima indikator dimensi empathy mendapat penilaian yang cukup puas dari masyarakat, yaitu perhatian, keramahan, kesedian mendengar keluhan, berperilaku adil dan kemudahan mendapat informasi. Indikator keramahan sikap pegawai mendapatkan respon yang paling tinggi kepuasannya dibandingkan empat indikator lainnya. Indikator yang memiliki kontribusi terbesar pada dimensi empathy, yiatu perhatian, kesediaan mendengar keluhan dan berperilaku adil. Sedangkan dari dimensi tangible, empat indikator dimensi tersebut mendapat penilaian yang cukup puas dari masyarakat, yaitu kerapihan, kenyamanan ruang tunggu, kebersihan ruang tunggu dan memiliki tempat parkir yang luas.

Tabel 2 Loading faktor dimensi kualitas pelayanan

\begin{tabular}{lrr}
\hline \multicolumn{1}{c}{ pelayanan } & \multicolumn{1}{c}{$\begin{array}{c}\text { Loading } \\
\text { Factor }\end{array}$} & \multicolumn{1}{c}{ T-value } \\
\hline Reliability & $-0,11$ & $-0,70$ \\
Responsiveness & 0,00 & $-0,02$ \\
Assurance & $-0,14$ & $-1,01$ \\
Empathy & 0,61 & 3,72 \\
Tangible & 0,41 & 3,75 \\
\hline
\end{tabular}


Indikator kenyamanan ruang tunggu mendapatkan respon yang paling tinggi kepuasannya dibandingkan dengan empat indikator lainnya. Indikator yang memiliki kontribusi terbesar pada dimensi tangible, yiatu kerapihan pegawai dan memiliki tempat parkir yang luas. Untuk dimensi empathy dan tangible memiliki kontribusi yang positif dan signifikan terhadap peningkatan kepuasan masyarakat. Besarnya kontribusi dimensi empathy dan tangible terhadap kepuasan masyarakat ditunjukan oleh nilai loading factor dari dimensi empathy dan tangible yang mana masingmasing dimensi memiliki nilai sebesar 0.61 dan 0.41 dengan arah positif, artinya semakin baik kualitas pelayanan empathy dan tangible maka kepuasan masyarakat semakin meningkat.

\section{PEMBAHASAN}

Hasil penelitian menemukan bahwa dimensi emphathy dan tangible paling berpengaruh terhadap tingkat kepuasan masyarakat. Sejalan dengan hasil penelitian yang dilakukan oleh Rezha, Rochmah, dan Siswidiyanto (2013) bahwa kualitas pelayanan berpengaruh positif terhadap kepuasan masyarakat dalam mendapatkan pelayanan perekaman e-KTP di Kota Depok. Berdasarkan temuan tersebut, maka dapat diketahui upaya prioritas perbaikan kualitas pelayanan berdasarkan dimensi kualitas pelayanan. Upaya prioritas pertama yang dilakukan oleh Kantor Pertanahan Kabupaten Indramayu adalah pada dimensi empathy yang memberikan kontribusi terbesar dalam meningatkan kepuasan masyarakat terhadap pelayanan pendaftaran tanah sebesar 0,61 . Kantor Pertanahan Kabupaten Indramayu perlu melakukan upaya peningkatan kualitas pelayanan.

Upaya prioritas selanjutnya yang dapat dilakukan Kantor Pertanahan Kabupaten Indramayu dalam memperbaiki kualitas pelayanannya yaitu pada dimensi tangible dengan nilai kontribusi terhadap peningkatan kepuasan masyrakat sebesar 0,41 indikator yang paling dominan dalam membentuk dimensi tangible adalah pemeliharaan informasi papan pengumuman dan kerapihan penampilan pegawai. Hal ini dimaklumi karena peranan penting papan pengumuman sebagai tempat untuk mendapatkan informasi mengenai kepemilikan tanah yang akan diterbitkan sertifikatnya harus bersih dan rapih. Hal ini dimaksudkan agar informasi di papan pengumuman dapat terbaca secara jelas oleh masyarakat. Sebagian besar kondisi kertas yang berisi informasi di papan pengumuman kotor. Hal ini dikarenakan papan pengumuman yang digunakan untuk menempatkan informasi tersebut dalam kondisi terbuka sehingga cepat sekali kotor dan mengalami kerusakan. Selain itu, penempatannya juga ditempatkan dibelakang. Apabila ketika masyarakat membuka tumpukan kertas di papan pengumuman satu per satu tidak secara hatihati maka dapat mengganggu kenyamanan masyarakat dalam mendapakan informasi di papan pengumuman. Oleh karena itu, kantor pertanahan perlu meningkatkan upaya pemeliharaan papan pengumuman secara intensif sehingga dapat dihindari tidak terbacanya informasi di papan pengumuman.

Hasil penelitian ini sesuai dengan temuan penelitian Sutadi (2008) yang menyatakan bahwa dimensi tangibles dan emphaty memiliki kontribusi yang paling tinggi diantara ketiga dimensi lainnya. Suharno (2002) menyatakan bahwa persepsi kepuasan masyarakat sangat ditentukan pada dimensi tangible baik dari segi kantor maupun pegawainya. Sedangkan menurut Azizah (2008) bahwa dimensi yang paling berpengaruh adalah dimensi empathy dan relaibility. Ketiga penelitian tersebut dilakukan di kantor pertanahan dengan tempat berbeda tetapi topik kajian yang sama.

Selain itu, hasil penelitian Dariah (2008) menunjukkan bahwa faktor-faktor kualitas pelayanan jasa yaitu keandalan, daya tanggap, kepastian, empati, dan bukti fisik baik secara parsial ataupun simultan mempunyai pengaruh yang signifikan terhadap kepuasan masyarakat oleh Kantor Pertanahan Kota Banjarmasin. Dimensi keandalan mempunyai pengaruh paling kuat terhadap kepuasan masyarakat pada Kantor Pertanahan Kota Banjarmasin. Purwanto (2012) menunjukkan bahwa indikator yang masih rendah dalam pelayanan di Kantor Pertanahan Kabupaten Semarang, yaitu prosedur pelayanan, persyaratan pelayanan, kejelasan petugas, dan kedisiplinan petugas. Hasil dua penelitian tersebut berbeda dengan hasil penelitian di Kantor Pertanahan Kabupaten Indramayu dalam hal dimensi dan indikator yang paling berpengaruh.

Menurut hasil penelitian Kuncoro (2008) menunjukkan bahwa indikator dalam dimensi tangible, yaitu sarana dan prasarana kantor memberikan kontribusi yang paling besar dalam meningkatkan kualitas pelayanan. Kemudian penelitian Cahyono (2011) menunjukkan bahwa sikap para pegawai dalam dimensi empathy di Kantor Pertanahan Kabupaten Jepara berpengaruh paling signifikan terhadap kepuasan masyarakat. Jahuri (2008) menyatakan bahwa 
pelayanan pensertifikatan yang diberikan pada Kantor Pertanahan Kotamadya Jakarta Timur belum bisa memberikan kepuasan pada masyarakat antara lain indikator ketepatan penyelesaian sertifikat, keikhlasan pegawai dalam memberikan pelayanan, kesiapan pegawai, keberadaan loket pelayanan, ketepatan janji pegawai, kepastian biaya, kesederhanan prosedur pelayanan, dan kemampuan pegawai dalam memberikan pelayanan. Sedangkan Supraworo (2009) menunjukkan bahwa dimensi emphaty sangat berpengaruh terhadap kepuasan masyarkat di Kantor Pertanahan Kabupaten Semarang.

Beberapa penelitian lain yang relevan tentang kepuasan masyarakat antara lain: (1) penelitian James (2003) yang melakukan analisa kepuasan pelanggan terhadap pelayanan PT. Wyranda Utama Makassar dengan menggunakan analisis kuadran, dan analisis CHAID dengan hasil penelitian menunjukan bahwa pelanggan PT. Wyranda Utama yang menyatakan puas terhadap pelayanan perusahaan sebesar $52 \%$, (2) penelitian Purnaditya (2004) yang melakukan analisis pelayanan giran bank none dalam rangka meningkatkan penghimpunan dana murah yang menggunakan analisis cochran cluster, analisis importance performance dan analisis tabulasi silang dan hasilnya dalam menghadapi giran loyalist maka atribut uang yang ditransfer cepat sampai, pelayanan cepat dan prosudernya tidak berbelit-belit menjadi prioritas utama yang harus diperbaiki oleh manajemen.

Hasil penelitian sebelumnya yang berjumlah tiga belas, tujuh diantaranya sesuai dengan hasil penelitian ini. Oleh karena itu, hasil penelitian ini dapat diasumsikan memberikan penguatan terhadap hasil penelitian yang lainnya. Penelitian lain yang sedikit berbeda, yaitu dalam hal dimensi yang paling berpengaruh terhadap kepuasan masyarakat pada pendaftaran tanah di Kantor Pertanahan masing-masing. Dimensi yang paling berpengaruh, yaitu reliability dan assurance. Perbedaan hasil ini disebabkan adanya perbedaan sistem pengorganisasian dan adat istiadat (kearifan lokal), serta teknik analisis yang berbeda. Sementara itu, tiga penelitian lainnya yang membedakan dengan penelitian ini, yaitu teknik analisi dan objek penelitian, tetapi masih kajian tentang kepuasan pelanggan atau masyarakat.

\section{SIMPULAN DAN SARAN}

Berdasarkan hasil penelitian diperoleh, tingkat kepuasan masyarakat terhadap kualitas pelayanan di Kantor Pertanahan Kabupaten Indramayu secara keseluruhan sudah cukup puas. Dimensi yang paling berpengaruh terhadap kepuasan masyarakat, yaitu emphaty dan tangible. Dari hasil tersebut dapat diperoleh beberapa alternatif kebijakan yang dapat ditempuh oleh Kepala Kantor Pertanahan Kabupaten Indramayu, yaitu membuat sistem komunikasi yang terintegrasi, penambahan jumlah pegawai dan pembinaan terhadap pegawai melalui pelatihan.

Perlu adanya upaya peningkatan partisipasi masyarakat dalam kegiatan pendaftaran tanah untuk memperlancar proses pelayanan pendaftaran tanah melalui: (a) pemberian motivasi kepada masyarakat untuk segera melengkapi berkas permohonan dengan membantu memberikan solusi yang dihadapi masyarakat dalam pemenuhan berkas kelengkapan, (b) meningkatkan kesadaran masyarakat untuk turut memelihara fasilitas fisik informasi papan pengumuman dengan memberikan slogan pada tiap papan informasi pengumuman untuk turut memelihara fasilitas yang disediakan bagi masyarakat, dan (c) meningkatkan peran aktif masyarakat untuk dapat memahami informasi pelayanan melalui sosialisasi baik secara tertulis di kantor pertanahan maupun secara lisan melalui penjelasan pegawai dan penyuluhan-penyuluhan di setiap wilayah kewenangan urusan pertanahan Kantor Pertanahan Kabupaten Indramayu. Model kepuasan masyarakat dalam penelitian ini relatif masih sederhana sehingga perlu adanya pengembangan model kepuasan yang lebih baik lagi dengan memperhatikan ketepatan indikator pembentuk. Selain itu kompleksitas hubungan antarvariabel indikator sesuai dengan realitas dilapangan (kondisi nyata).

\section{DAFTAR PUSTAKA}

Azizah. (2008). Analisa kepuasan terhadap pelayanan pendaftaran tanah (Kasus: Kantor Pertanahan Kabupaten Bogor (tesis). Magister Manajemen dan Bisnis, Institut Pertanian Bogor, Bogor.

Barata. (2006). Dasar-Dasar Pelayanan Prima. Jakarta, ID: Elex Media Komputindo Kelompok Gramedia.

Cahyono, A. (2011). Persepsi pelanggan terhadap pelayanan publik di kantor pertanahan: Kantor Pertanahan Kabupaten Jepara (tesis). Magister 
Manajemen dan Bisnis, Institut Pertanian Bogor, Bogor.

Dariah. (2008). Pengaruh kualitas pelayanan terhadap kepuasan masyarakat dalam mengurus sertifikat tanah pada kantor pertanahan: kantor pertanahan Kabupaten Banjarmasin. Jurnal Media Mahardika, 12(7).

Jahuri, A. (2008). Analisa kepuasan masyarakat terhadap kualitas pelayanan pensertifikatan tanah: Kantor Pertanahan Kotmadya Jakarta Timur (tesis). Magister Manajemen dan Bisnis, Institut Pertanian Bogor, Bogor.

James. (2003). Analisa kepuasan pelanggan terhadap pelayanan PT. Wyranda Utama Makassar (tesis). Magister Manajemen dan Bisnis, Institut Pertanian Bogor, Bogor.

Kotler, P. (2000). Principles of marketing. New Jersey, US: Prentice Hall.

Kuncoro, S. (2008). Kepuasan masyarakat terhadap kualitas pelayanan pendaftaran tanah sistematik: Kantor Pertanahan Kota Depok (tesis). Magister Manajemen dan Bisnis, Institut Pertanian Bogor, Bogor.

Mouw, E. (2013). Kualitas pelayanan publik di daerah. Jurnal UNIERA, 2(2). 92-103.

Parasuraman, A (1988), A multiple scale for measuring consumer perceptions of service quality. Journal of Retailing, 64(1), 12-40.

Purnaditya. (2004). Analisis pelayanan giran bank none dalam rangka meningkatkan penghimpunan dana murah (tesis).
Magister Manajemen dan Bisnis, Institut Pertanian Bogor, Bogor.

Purwanto. (2012). Analisis faktor-faktor yang mempengaruhi kualitas pelayanan pengurusan sertifikat tanah di Kantor Pertanahan: Kantor Pertanahan Kabupaten Tulungagung. Jurnal IImu Manajemen, 1(1).

Rezha, F., Rochmah, S., \& Siswidiyanto (2013). Analisis pengaruh kualitas pelayanan publik terhadap kepuasan masyarakat (studi tentang pelayanan perekaman Kartu Tanda Penduduk Elektronik (e-KTP) di Kota Depok). Jurnal Admininstrasi Publik (JAP), 1(5), 981-990.

Suharno. (2002). Persepsi masyarakat terhadap pensertifikatan tanah (kasus di Desa Girikerto Kecamatan Turi Kabupaten Sleman). Jurnal Pertanahan, 2.

Sumarwan, U., Jauzi, A., Mulyana, A., Karno, B. N., Mawardi, P. K., \& Nugroho, W. (2011). Riset pemasaran dan konsumen. Bogor, ID: IPB Press.

Supraworo, J. (2009). Analisis Indeks Kepuasan Masyarakat (IKM) terhadap Kinerja Pelayanan Publik Bidang Pertanahan dalam Proses Balik Nama: Kantor Pertanahan Kabupaten Semarang (tesis). Magister Manajemen dan Bisnis, Universitas Diponegoro, Semarang.

Sutadi. (2008). Analisa kepuasan pelayanan pendaftaran tanah di kantor pertanahan Kota Jambi Provinsi jambi (tesis). Magister Manajemen dan Bisnis, Institut Pertanian Bogor, Bogor. 